\title{
Independence, Democracy and Institutional Choices $^{1}$
}

\section{Rui Graça Feijó}

Universidade de Coimbra

\begin{abstract}
This paper proposes to celebrate the $10^{\text {th }}$ anniversary of the independence of Timor-Leste by focusing on two controversies that marked the period before its proclamation and whose consequences extend into the present. The first one deals with the "road map to Independence" and comprises the debate on the best process to elaborate a Constitution. It is intertwined with the problem of the extent to which Timorese ought to participate in the critical decisions of the transitional period, conducted under the aegis of the United Nations. The second impinges on the choice of its system of government and its impact on the consolidation of democracy. This section discusses the relevant literature on semipresidentialism to frame a comparative perspective to events in Timor-Leste and shows the historical evolution of the process of constitutional design and the debates it involved. Finally, this essay proposes to look at those critical choices as a function of the history of Timor-Leste since 1975 and the political balance of forces rather than derived from theoretical principles.
\end{abstract}

Keywords: Timor-Leste, Constituent Assembly, Popular Consultation, Semi-presidentialism, Inclusive Governance, Democratic Consolidation.

\section{Celebrating}

The Democratic Republic of Timor-Leste is celebrating the tenth anniversary of its newly proclaimed Independence. When the flag of the first new nation of the third millennium was raised in Taci-Tolu, at midnight on May 20, 2002, before a crowd of Timorese and illustrious guests that included Indonesian President Megawati Sukarnoputri, Portuguese President Jorge Sampaio, UN 
Secretary General Kofi Annan, and President Bill Clinton, the country had a Constitution drafted by an Assembly specially elected for the effect, which had decided to transform itself into the first legislative chamber and was the main source of legitimacy for the country's government; the Resistance leader had been elected by a landslide for the Presidency of the Republic in a competitive, free and fair election; and a vivid memory persisted of the vote organized under the aegis of the United Nations on August 30, 1999, which paved the way to breaking away from Indonesian rule and establishing an independent Timor-Leste. Democracy is thus written in the genetic code of Timor-Leste, and it is timely to recall that the new country also celebrates ten years of continuous democratic rule.

Timorese democracy is today established and fits international criteria. In 2010, the Center for Systemic Peace's Polity IV Project rated the Timorese regime at 7 points on a scale from -10 to +10 , in which only grades between +5 and +10 are democracies. Freedom House has consistently rated TimorLeste as an "electoral democracy" and "partly free" country since Independence, noting that Political Rights deserve a mark of 3 throughout, whereas Civil Liberties oscillate between 3 and 4, on a scale in which 1 marks the top and 7 the lowest. These markings signify that there is still a way to go to a consolidated democracy that fulfils all the international criteria and those of the country's own constitutional provisions: to strengthen the judiciary system and guarantee its independent status, control violence and discipline police forces, safeguard freedom of the press, implement legislation allowing the staging of referendums, and much more. Increasing the quality of democracy, a process intertwined with the very consolidation of democracy, is an open-ended road.

These ten years as an independent country have been marked by several incidents. The United Nations maintains a medium-profile unit in Timor-Leste (UNMIT-United Nations Integrated Mission in Timor-Leste), and international military and police forces remained in the territory until the end of 2012. Nevertheless, the Constitution has been kept in force throughout the period, and political solutions for the most critical events were achieved within the rule of law. The recent round of presidential and parliamentary elections marked the end of the second political cycle of independent Timor-Leste. The staging 
of internationally acknowledged free and fair elections in a regional context where these cannot be taken for granted has revealed a stabilized democracy, although the eruption of disturbances in the aftermath of the legislative elections has reminded all stakeholders that consolidation is an unfinished process.

The history of this success is not linear and comprises several episodes of significant controversies. Critical choices were made, many bearing on how democracy might be implanted and stabilized, all of which cannot be discussed here. This essay focuses on two episodes, aiming to highlight the complexity and open nature of the historical process as a requisite for understanding the strengths and weaknesses of institutional choices and their relation to democratic consolidation. First, a discussion is proposed of the calendar (and its correlate issues) that was observed under UN administration related to the path to Independence, including the decisions surrounding the election and the mandate of a Constituent Assembly (CA). Behind the screen of internationally acknowledged democratic procedures, a substantial, far-reaching debate on the nature of the transition process and the forms of involvement of the Timorese in the design of their own future was entertained. Second, the choice of a government system by the CA is considered both in terms of the historical and political factors that explain its emergence and adaptation to the Timorese situation, and the theoretical debate on the relationship between semi-presidentialism and democratic consolidation. Both sets of decisions were taken before Independence, but their influence would spread well into the first decade of the new nation.

\section{A Controversial Roadmap Towards Independence}

2a. Historical Background

UN Security Council Resolution 1272 of October 25 1999, promulgated in the wake of the surge in violence that ensued the announcement of the Popular Consultation's results and the deployment of INTERFET (an international armed force), established the United Nations Transitional Authority in East Timor (UNTAET). This mission was charged with overall responsibility for the administration of Timor-Leste. The magnitude and extension of its powers were a novelty in similar processes that involved the international community (Tansey 19), prompting one observer to label it "the UN kingdom of East 
Timor" (Chopra 27). Transitional Administrator (TA) Sergio Vieira de Mello established his own competences through Regulation no 1999/1 (27 November) in such a manner that he was regarded as a "pre-constitutional monarch." Others dubbed the process "benevolent despotism," pointing to the paradox of attempting to introduce democratic rule through authoritarian means. ${ }^{2}$ The Regulation reads:

\begin{abstract}
All legislative and executive authority [...] including the administration of the judiciary is vested in UNTAET and is exercised by the Transitional Administrator (section 1.1.).
\end{abstract}

It was expected that "[i]n exercising these functions the Transitional Administrator shall consult and cooperate with representatives of the East Timorese people" (section 1.1.). However, the UN Security Council (UNSC) Resolution did not specify how the shift from the transitional administration to an independent new nation would occur, nor did any agreement exist along the lines of those of Cambodia or Afghanistan that might define the bases for the state-building effort (Aucoin and Brandt 254). A need was felt to find "a delicate balance between imposing international standards and acknowledging the local historical and political context" (Charlesworth 329). The proclamation of intentions contained in the Resolution led Vieira de Mello to issue Regulation 1999/2 (2 December) with "the purpose of establishing a consultative mechanism that ensures the participation of the East Timorese people in the decision-making process," also establishing a 15-member National Consultative Council (NCC). Despite references to "decision-making," section 1.1 stipulates that the Council was established to "provide advice to the Transitional Administrator." It was conceived as "a joint consultative forum of representatives of the East Timorese people and UNTAET" that could not "prejudice the final authority of the Transitional Administrator" (section 1.3), who chaired it (section 2.6). The Timorese composition of the NCC included seven representatives of CNRT, three from "political groups outside the CNRT which were in existence prior to 30 August" (i.e., groups that had supported integration), and one from the Roman Catholic Church. ${ }^{3}$ 
This approach bears the marks of a major decision that occurred behind the scenes, in New York: the shift of the Timorese file from the UN Department of Political Affairs (UNDPA) which had been responsible for its development over the years, including the organization of the Popular Consultation, to the UN Department of Peace Keeping Operations (UNDPKO) (Garrison 8). The former had extensive knowledge of the political landscape and entertained relations with the major figures of the Resistance, whereas the latter advocated a novel attitude based on neutrality principles that apply in post-conflict situations in which rival parts face each other, but was difficult to justify in the case of Timor-Leste. One of the conflicting parts had withdrawn from the scene, but no 'political void' ensued, as often was assumed; independence had been gained through peaceful and legitimate means and was supported by an important political organization that had been recognized by UNAMET. But some had apparently not realized that the conflict was actually over.

The resulting strategy was not satisfactory. According to Pedro Bacelar de Vasconcelos, "UNTAET did not understand an elemental truth: it is the people who build democracy from the first instant" (2). He added,

\footnotetext{
The new Transitional Administration sacrificed to its own organizational interests, the preservation of its sovereign status, its conveniences for technical equipment, and the growth of its bureaucratic apparatus, the precious capital it had inherited from UNAMET's esteemed experience. ${ }^{4}(3)$
}

Soon Sergio Vieira de Mello became aware of the serious frustration among Timorese leadership due to their subordinate role, and he accepted the idea that "Timorization" of the administration had to be encouraged at all levels (Powell 328-331).

CNRT convened a conference at Tibar in late May 2000 to analyze prospects for the future, and reaffirmed its commitment to a strategic plan for drafting a constitution through a "constitutional convention" with ample public consultation agreed in April 1999 in Melbourne. According to Aucoin and Brandt, at this conference, UNTAET Department of Political Affairs under Peter Galbraith proposed an alternative path: "[e]lections will choose a Constituent 
Assembly which in turn will write, debate and adopt a constitution." (ETTA 27) The Transitional Administrator was careful to keep doors open at CNRT's Congress in August, stating clearly to delegates that both options were legitimate. But in September he addressed the UN Security Council and only presented the plan to hold elections for a Constituent Assembly without reference to an eventual "constitutional convention" or any form of public consultation.

Meanwhile, after extensive negotiations with CNRT and lobbying at UN headquarters, Vieira de Mello issued Regulations 2000/23 and 2000/24 (July 14) establishing a "Cabinet of the Transitional Government" and a National Council (NC) to replace the moribund NCC, which was only appointed in October. This effort responded to UNSC Resolution 1338 (31 January 2001), which requested the TA to "continue to take steps to delegate progressively further authority within the East Timor Transitional Administration to the East Timorese people." The first document "aimed at effectively governing and administering East Timor during the transitional period," and comprised four Timorese and four international "Cabinet Officers" appointed by the TA. All Cabinet decisions were "subject to the review and approval of the Transitional Administrator" (section 4.3.). The National Council was set up "for the purpose of establishing a legislative mechanism," and was composed of 33 Timorese in representation of relevant organizations (section 1.1.) who had the power to elect their own chairman (section 4). The TA retained powers to approve "in his sole discretion" the draft regulations produced by the Council (section 2.3.). The inversion of normal democratic procedures, maintaining the legislative dependent on the chief executive, remained in force.

Despite a marked improvement in the engagement of Timorese leadership in matters pertaining to transition, the sentiment that "ownership of the process" was in foreign hands did not subside. A substantial number of political actors could not understand why the results of the popular consultation-in which the symbol of CNRT had been used to signal Independence-were not translated into actual transfer of power. As relations with UNTAET grew strained, the proclamation of Independence emerged as the only way to achieve such a goal. Dissention in the ranks of CNRT led to FRETILIN and UDT withdrawing from the organization, soon followed by Xanana's decision to disband it (August 2001). 
$2 \mathrm{~b}$. The Roadmap to Independence

At the end of 2000, NC discussed a road map concerning steps towards full independence and their calendar. The Council referred the matter to its Political Affairs Committee (PAC) where Aniceto Guterres, Milena Pires, Salvador Ximenes and Agio Pereira sat beside Xanana. This group "felt it necessary and important to conduct a consultation process."

The Timorese leadership was torn between two conflicting considerations. They recognized the immense difficulty of the tasks ahead and the need for time to lay the foundations of the new state, and were bound by earlier decision pointing to a five to ten year transitional period; on the other hand, they felt marginalized in the decision-making process by the domineering presence of the UN administration and sought to assume rapid control over the destiny of their country. Unsurprisingly, two major lines of argument were presented before the PAC: one favoring a protracted period of transition to independence which could be coupled with an increased role for the Timorese in the process, another supporting a rapid move and adopting the view that setting up formal democratic institutions and staging competitive elections was a requisite for independence.

The first vision was rooted in the history of the Timorese Resistance. RamosHorta's speech in Oslo on the occasion of his acceptance of the Nobel Peace Prize proposed a transitional period from Indonesian rule lasting up to ten years. A similar lengthy period was agreed upon when the various branches of the opposition to Indonesian rule met in Peniche, Portugal, in April 1998, and formed the new CNRT. Its rationale was twofold: it offered Indonesia the time to organize an eventual withdrawal without turbulence, safeguarding its interests, and it offered the Timorese themselves time to heal the scars of past disputes that only recently had been overcome by their political elite represented in the CNRT. If the first argument had been overturned by the sequence of events that followed the agreement of May 5,1999 , the second reason had not been disposed of, and remained a central concern of a sizeable part of the Timorese leadership. This view was not unanimous.

José Ramos-Horta appeared before the PAC on January 19, 2001 and stated:

In my modest opinion, it is better to move slow and sure so that as we reach the D-date (Independence), the institutions of the country, such as 
the Constitution, democratic assembly, courts, banks, investments, law of property and other law, including diplomatic relationships are established properly. Without forgetting at the same time as we are working on the calendar for independence, each one of us should bear in mind the need for peace, stability and security. Any acceleration of the process may jeopardize the question of peace, security and stability itself. (ETTA 17)

He further proposed that, according to views expressed by "various members of the CNRT and political parties" and discussed when Xanana was in home arrest at Salemba, a Constitutional Convention be organized along the same lines that led to the constitution of NC, but with a broader composition in order to secure ample participation. This Convention would draft a Constitution, benefitting from the counsel of international experts.

Once this job is done, with a document in hand, such document would be submitted to an elected constituent assembly [...], a democratic body elected by the people to study the project that would come from the constitutional convention, make some changes, but with a mandate not to go beyond one month. Immediately the constituent assembly would then vote to ratify the final product and East Timor would have its Constitution (idem, p. 17).

In brief, Ramos-Horta pleaded for the continuation of political work based on the imperatives of consensual democracy through the enlarged participation of all streams of opinion, and disposing of time and power to organize wide public consultations, which should precede the opening up of a second phase with competitive mechanisms and majority rule only when sound bases had been established on various fronts. In its broad outline, this position was supported by the majority of those who testified before the PAC, including representatives of several political parties and other organizations.

The Catholic Church, through Bishop Ximenes Belo-who had long taken public positions along similar lines (Smythe 40), presented a document on February 9, which reads:

The Constitution is like the house of our dreams. You cannot build it overnight $[\ldots]$. A Constitution is not satisfactory unless all major groups and 
political interests in the society are agreeable to the terms of the Constitution. The Constitution should be a document of the people. Such agreement only comes after a process that is truly inclusive, consultative and responsive to the different perspectives in the community (ETTA, "Constitution Making and Process. Church Position," 2)

A similar point of view was reported by the representative of the Jurists' Association, Adérito Soares: "The Constitution is something that needs to be written through the blood and sweat of the people of the nation" (ETTA 44).

Among those who expressed views on behalf of the "civil society," Joaquim Fonseca (NGO Yayasam HAK) put things bluntly:

We feel that there has been a rush linked to the timetable that relates more to UN priorities and the priorities of some political leaders rather than the priorities of the people to make up their mind (ETTA 57).

Curiously enough, no statement is reported from FRETILIN, in either official or individual form. It is known that this party opposed this approach and actually sided with high-ranking international officers, some of whom also appeared before the PAC, in defending an alternative path, as they had already done at CNRT convention in Tibar. This was clear in several testimonies. Finn Reske-Nielsen, by then the leader of the local UNDP station, wrote:

The proposed calendar [i.e., elections for a constituent assembly by mid2001] is, I believe, tight but realistic. Nevertheless, it is going to require a lot of hard work and dedication on everyone's part to successfully go through the process of establishing political parties, agreeing on an appropriate electoral system, ensuring effective and transparent registration of voters, conducting elections in an atmosphere free of fear and intimidation and building a consensus on the constitutional arrangements for a free and independent East Timor (ETTA Annex).

The optimistic view that much depended on voluntary action capable of removing the most serious obstacles in a matter of weeks or few months was 
coupled with the paternalistic notion that the whole process should move topdown and from the centre to the periphery:

One of the most important challenges in the transitional period is to disseminate appropriate information to the electorate to ensure that everyone is fully cognizant of his or her rights and obligations in a democratic state, that he or she is well informed about the available political choices, etc. In this regard the UNDP has been asked by ETTA to draft "action plan on national framework on civic education" under the guidance of the TA and the newly established National Steering Committee on Civil Education (idem, Annex).

The most outspoken proponent of this path was Peter Galbraith, Cabinet Officer in charge of Political Affairs and Timor Sea. The terms of his testimony could hardly be more explicit:

The final phase of Political Transition begins with the election of a Constituent Assembly with a mandate to prepare the constitution for an independent Timor-Leste. UNTAET has an obligation to hold free and fair elections that meet the highest international standards and are open to all political parties and viewpoints. Only in this way can UNTAET be certain that it is turning power over to bona fide representatives of the Timorese people. ${ }^{6}$ The Constituent Assembly will have full plenary power. It can decide on the type of constitution, the method of drafting the constitution, the extent of debate on its adoption, and the method of ratification. Both theoretically and practically, it will be impossible for an un-elected National Council and Cabinet to limit the scope of the Constituent Assembly writing authority (ETTA 27).

Together with other high-ranking international officers, Galbraith was concerned with an "exit strategy" for UN involvement in Timor-Leste. They were clearly preoccupied with finding the quickest and least expensive exit that would still meet expected international standards and protect the UN against 
international criticism (Garrison 2). They were aware of Kofi Annan's view that the whole process should not extend beyond two to three years, thus suggesting an ambitious mandate and a tight timetable. In this light, all other considerations were overridden by a procedural concept holding that competitive elections are the ne plus ultra of democracy and must be organized at all costs. They are indeed regarded as a prerequisite for the attribution of legitimate status to any sort of polity. UNTAET Electoral Affairs Division under his supervision had, as of December 2000, prepared 8 working papers detailing "basic electoral decisions and criteria for choice," which were circulated to NC members. ${ }^{7}$

Galbraith and his allies won out, and NC adopted a recommendation including the staging of elections for a Constituent Assembly by mid-2001 as a fundamental step towards guaranteeing the conditions for independence. However, NC also took note of the reservations and objections pertaining to the short time allowed for its preparation, the need to foster popular participation in the process, and the defense of gradual methods leading up to the final election of such assembly. In this vein, NC adopted two further statements. First, it took upon itself "the responsibility of organizing a National Convention for the purpose of drafting, debating and adopting a Pact of National Unity" (Recommendations, B.1). This would imply that

the Constituent Assembly [...] adheres to a Pact of National Unity which includes respecting the results of the Popular Consultation of $30^{\text {th }}$ August 1999, obeying the principles consecrated in the Magna Carta approved in the first CNRT National Convention held in 1998, and practice democracy at all levels of the party structures' (B.4). ${ }^{8}$

This document was effectively drafted and subscribed by all but two parties running in the August 2001 election. Second, NC also resolved to "establish a National Constitutional Commission to facilitate the process of consultation throughout the 13 districts of Timor-Leste" (C.1), the results of which were to be handed to the Constituent Assembly upon its election.

Compromise was thus obtained on a calendar that reduced the chances of the National Constitutional Commission carrying out significant work due 
to the short time made available for that purpose. Meanwhile, through the Pact of National Unity, NC imposed guidelines on the Constituent Assembly, thus actually limiting its powers. Although a distinct attempt at a compromise between alternative strategies is discernible in the final outcome, Xanana felt uncomfortable with it and eventually resigned as chairman of NC in March on the basis of disagreements over the limitations to the consultation process (Garrison 23).

By late February 2001, the road map was completed and time had come to move along the chosen road. For UNTAET, the "early adoption of a new constitution would be a benchmark of success for the mission which needed to illustrate results to justify its huge expense" (Aucoin and Brandt 246). For the Timorese, the coveted prize of Independence overshadowed any shortcomings. Just as the elections for the Constituent Assembly were set in motion, Sergio Vieira de Mello disbanded the National Council (UNTAET Directive 2001/8, 14 July).

\section{2c. Before the Constitutional Draft...}

In accordance with the received recommendations, and for "the purpose of soliciting the views of the people of East Timor on the future Constitution of an independent and democratic East Timor, in coordination with civil society initiatives," Sergio Vieira de Mello established Constitutional Commissions in all 13 districts, via UNTAET Directive 2001/3 9 :

To obtain a broad spectrum of views, each of the Constitutional Commissions was required to conduct at least one public hearing in each of the 65 sub-districts. In addition, those wishing to do so could present their opinions and suggestions through written submissions or other means to the Commission. The Commissions were required, as far as possible, to consult with local leaders and other prominent persons, the Church, NGOs, and community groups. (UNTAET, A Report on the National Constitutional Consultation, Foreword)

Each Commission was required to present a report to the CA "reflecting the consolidated views expressed in those hearings" (idem). 
In spite of all the possible dedication on the part of members of those commissions, and the effort put to fulfill their mandate, this enormous task was to be performed in only one month. Earlier proposals had contemplated a full year as the minimum time span for such endeavor; this was the case with a proposal submitted to the NC by Aniceto Guterres on behalf of a leading human rights NGO, Yayasam Hak. In fact, 205 meetings were held between June 18 and July 14 . The reports of those meetings were handed over at a high-level ceremony on August 16 to Sergio Vieira de Mello, who then passed them on to the Constituent Assembly on its first day's sitting on September 17. One member of the commission speaking at the formal ceremony said:

They climbed mountains to reach far away places and held off weather, women and men, old people, the illiterate and the educated, everyone, small and big, school children not yet in university, primary school and university teachers, priests and nuns-tireless, without thirst or hunger, full of courage, with one thought in mind, with all their heart, to take part in this most valuable and precious task for the nation. Thirty eight thousand people! (UNTAET, A Report on the National Constitutional Consultation, Annex)

One can express sympathy for all their epic efforts. "They did wish to participate, and they had plenty of things that they wanted to say" (Lutz 3). But one cannot fail to notice that such a process was no more than a mockery of what had been actually suggested by people like Ramos-Horta or Aniceto Guterres. Gathering a crowd of several hundreds to discuss in one day more than two dozen "topics" ranging from the national flag to health and the organization of social services, religion and the police, official languages and the environment, is perhaps an adequate way to "disseminate" the value of having a document encompassing provisions on all those issues, but hardly a sound method to forge consensus or even to capture the views of "the people" on the basic tenets of a constitutional text. Besides, according to the Carter Center, many "felt that the consultation process had been United Nations-dominated, too short, and not representative of a genuinely East Timorese process" 10 (Carter Center 44). 
The reports exist, and are detailed as far as "the community's suggestions or desires to be included in the Constitution" go. However, the Constituent Assembly failed to consider them as working documents along political parties proposals. Some cases of great symbolic nature (references to the 1975 proclamation of Independence, the flag, the use of the crocodile as the symbol of the nation) were openly contradicted by the Assembly. A few of the issues raised by citizens might have jeopardized the international standards expected from a modern Constitution-such as freedom to participate in public office, freedom of religion or the separation of Church and State-or were of a particularistic nature that made them unsuitable for a general law such as the Constitution (Lutz 2). Many others expressed simple views that would have been possible to accommodate, like the desire to define a strong mandate for the President.

\section{2d ...And after}

After the Assembly completed its draft of the Timorese Constitution (February 9), another process of "consultation and socialization of the constitutional text" was organized. Teams of deputies were staffed with representatives of different parties and dispatched to the districts by virtue of a February 20 decision. ${ }^{11}$ FRETILIN and ASDT opposed a move to offer this process one full month's time to accomplish its mission, insisting it should be completed in one week (Baltazar 5). Meetings were held again at sub-district level. For instance, one group organized a meeting on February 25 at the Community Centre of Viqueque from 10 am to $6 \mathrm{pm}$, with a thousand people attending, 49 of whom took the floor; the next day, they moved to the school in Dilor, where 1,200 people gathered between 10:30 am and 3:30 pm, 27 of them having asked to speak.

A survey of the minutes of those meetings allows us to consider that two sorts of interventions were made at this point. Political parties that had presented proposals to the CA which were rejected (for instance, against its transformation into the first legislative chamber), made an appeal to local militants to come before the commission and defend those views. On that specific and prominent issue, FRETILIN, which had voted in favor, mobilized and presented documents with hundreds of signatures; the same happened with those who had opposed the move and supported fresh elections after the approval of 
the Constitution. On the other hand, several issues were raised in a spontaneous manner-mostly concerned again with symbolic matters (independence day, the flag, languages, religion, the figure of the President). Minutes were taken and presented before the CA within the deadline of March 2.

The "Commission for Systematization and Harmonization" selected proposals that did not, among other criteria, collide with "the unity and internal coherence of the draft constitution," such as the inclusion of a mention of God in the oath of any new President. Recommendations from the popular consultations were merged with those received from different organizations of "civil society" whose advice had also been sought. Eight recommendations from the consultation process in the districts were included in the twenty-one amendment proposals that the Commission presented to the Plenary, only four of which were adopted by the Constituent Assembly (Baltazar 6).

The "popular consultation process," both before and after the drafting of the constitutional text, is important per se-not for the results it eventually yielded, but inasmuch as it reveals existing tensions. Those opposed a dominant discourse on the virtues of participatory democracy (which required at least the payment of lip service), and the pragmatic options of UNTAET and one of the Timorese political forces-FRETILIN - that emphasized the superior legitimacy of the electoral procedures over the "new constitutionalism" as defended by a host of Timorese political players (Garrison 12-14). According to Nancy Lutz, "many national and international political advisors felt that public consultations [...] would be the most effective tool for integrating East Timorese people in the political and constitutional process", and "were seen as critical for public awareness and public 'ownership' of the new nation's constitution"- but in "neither the first nor the second set of consultations were the suggestions compiled at the village and sub-district level ever seriously considered by the Constituent Assembly" (1). One should note the assertion by Simon Chesterman that "local ownership is the intended end of any state-building operation." (2). However, the Carter Center noticed that the "energetic participation of citizens underscores the fact that the people of East Timor are deeply concerned that their voices be heard in their government bodies." (45)

The "road map" that had been accepted as a compromise, which consisted of a two-pronged approach combining the staging of competitive elections for 
the CA with the creation of mechanisms to embrace wider public participation in the drafting process, was virtually amputated. At the end of the day, the consultation process that was supposed to have permitted a wide participation of the population in the definition of its constitutional provisions and offered a mechanism for the elected deputies to entertain a dialogue with the society at large turned out to be perfunctory. The critical decisions and political bargaining were restricted almost exclusively for the elected members of the CA, disregarding other stakeholders. This may have affected the degree of legitimacy conferred to the Constitution among the people at large. According to Aucoin and Brandt, "it seems axiomatic that if constitutions are to serve as a social contract, it is critical that the process be as inclusive as possible" (270). However, it may not have had the same frustrating effect among the local elite, who was involved in the process. In this light, it is important to turn now to an episode that involves directly those elected to draft the Constitution: the choice of a government system.

\section{The Constituent Assembly and}

the Choice of Government System

3a. Semi-presidentialism and Democracy

Timor-Leste chose semi-presidentialism as its system of government. Semipresidentialism has gained the status of a tertium genus among democratic systems of government alongside the long-established parliamentarism and presidentialism. It has also gained popularity over the last decades in the context of the expansion of "the third wave of democracy." 12

Definitional issues have marred the debate on this model ever since Duverger offered the first contributions in the late 1970s. Two conditions for this classification have been established: the election of both the President of the Republic and the Parliament by popular vote, thus establishing a duality of power at the core of the system (Sartori 127). Duverger's initial proposal considered a third condition-the existence of somewhat ill-defined "extensive powers" in the hands of the President-which Elgie has recently proposed to drop from the definition and re-integrate in the analysis of specific forms of 
this model (6). This essay follows Elgie's position to ground the classification of Timor-Leste as semi-presidential and allow for comparative approaches, although the powers of the President might be regarded as sufficiently ample to be accommodated in the narrower definition of Duverger. ${ }^{13}$

For several decades, the merits and perils of semi-presidentialism were discussed on the basis of the experience of a specific country or small group of countries. This fact led discussions to focus on logical deductions and systemic inferences, and conclusions were thus largely hypothetical as to the articulation between this system of government and the consolidation of democracies (Pasquino 14). Recently, Sophie Moestrup has conducted the first large scope survey of democratic polities having or having had semi-presidential systems of government and related this to the survival or breakdown of democracies. Her conclusion was that on "average, semi-presidential young democracies have not performed better than presidential regimes" (43). Cheibub and Chernykh also found that semi-presidential countries should not be expected to be associated, in a systematic way, with the performance of democracies one way or the other ("Constitutions and Democratic Performance").

However, it has also been noticed for some time that semi-presidentialism can itself be regarded as a broad umbrella under which different sub-types can be discerned:

\footnotetext{
Semi-presidentialism is a very heterogeneous regime type and for this reason it is unlikely to be associated in toto with any political consequences. Instead, to understand the politics of semi-presidential countries, it is necessary to distinguish between different forms of semi-presidentialism. (Elgie 40)
}

Political literature has given ample credit to a proposal initially formulated by Shugart and Carey and later refined with other contributions (Lobo and Neto). Two major sub-types were identified: "president-parliamentary" and "premier-presidential." The key for this distinction impinges on the political conditions under which a prime minister governs: where the prime minister and his government are politically responsible solely to the legislature, a "premier-presidential" system is said to exist; where the prime minister and his 
government are responsible to both the legislature and the president, then the regime is of the "president-parliamentary" type. ${ }^{14}$

When these distinctions are taken into account, a causal link between the choice of the specific system of government and the performance of democracy seems to emerge. Elgie's recent work strongly suggests that "there is a direct causal link between the form of semi-presidentialism that a country has chosen and the democratic performance of that country" (35). This conclusion can further be divided in two statements:

a) President-parliamentary countries are more likely to witness a breakdown of democracy than those who adopted the premier-presidential type; and

b) Premier-presidential countries are likely to have a higher standard of democracy than president-parliamentary ones.

Samuels and Shugart have also stated that "no premier-presidential democracy has ever been replaced by an authoritarian regime" (195), thus supporting the idea that the two sub-types do affect the performance of democracy in different ways.

These findings are relevant to the debate on the merits of semi-presidentialism in processes of democratic consolidation insofar as they are supposed to reveal more than a statistical hazard and call for a systemic interpretation or a causal mechanism. The two forms of semi-presidentialism provide different incentive structures for political actors, and thus different causal mechanisms are at play:

[U]nder premier-presidentialism, the president can govern only through the legislature. Therefore, the president is encouraged to cooperate with the legislative. By contrast, under presidential-parliamentarism, the president and the legislature may have an incentive to govern against each other. (Elgie 183)

Elgie further distances himself from the eventual merits of presidentparliamentarism in general, and specifically in a situation akin to the one witnessed in Timor-Leste, when he writes: 
If the winning candidate is able to secure a very large percentage of the vote at what might be considered the "founding election," then the candidate may be in a position to choose a set of institutions that consolidate their hold over the political process. [...] [T] hey may be in a position to chose a presidential-parliamentary form of semi-presidentialism. In this case, the choice of president-parliamentarism may reflect an existing desire for autocratic rule. (53)

Timor-Leste might be regarded as a test case for Elgie's hypotheses, according to which there is a positive correlation between a choice of premierpresidentialism and the facilitation of democratic consolidation, and a possible link between president-parliamentarism and autocratic tendencies. If the Timorese choice fits with president-parliamentarism, our quest for a favorable explanatory cause for the stabilization of democracy in the country would find a quick answer. Conversely, if president-parliamentarism was the actual choice, this might contribute to explain some of the difficulties encountered in the consolidation of democracy. However, answers to the basic questions face some difficulties, and not all pertain to the methodological realm that sustains that political analysis is concerned with institutions that matter but hardly determine political outcomes. ${ }^{15}$ What sub-type of semi-presidentialism did Timorese actually choose: is it "premier-presidential"? How was the decisionmaking process conducted? How does one interpret the realm of presidential powers? Do elements revealing similarities with "president-parliamentary" imply a move away from the best democratic practices?

In order to fully understand what is at stake, I propose to venture into a brief history of the decisional process that led to the CA choice of a government system.

\section{3b. History and Politics of an Institutional Choice}

The CA was elected on August 30, 2001, two years after the Popular Consultation that paved the way for the political developments of which this election was a significant part. Seventy-five members were elected by proportional representation on party lists in a single national constituency, and each of the 
13 districts also elected a local representative on a first-past-the-post election. FRETILIN won the absolute majority of seats ( 55 of 88 ) but fell short of the 60 seats statutorily required to approve the Constitution without compromise (Sousa 24). Among the critical choices faced by the CA, the government system ranks high. This section deals with the controversies surrounding its inception.

It is not easy to document the background to this issue. ${ }^{16}$ According to various sources, when CNRT was created in 1998, electing Xanana Gusmão as its chairman, it was assumed that the political model of the future country would be inspired by the structure adopted for its own organization. The role of a President would be prominent, but no detailed configuration was discussed at such an early stage. Some have suggested that a "presidentialist" model was envisaged, but before sound evidence is produced that goes beyond terminology (often used without precise technical definitions in mind) one should limit findings to the fact that the leadership of Xanana Gusmão was widely accepted both for the current moment and for subsequent stages. The issue resurfaced in 1999 after the May 5 agreement. CNRT leadership met in June in Salemba, where Xanana was serving his prison sentence, and issued a statement that supposedly alludes to a vague presidentialist model. After another meeting in Darwin in the wake of the release of the Resistance leader, CNRT issued a "transition plan" that is said to contain a reference to "semi-presidentialism." CNRT's plan for transition recognized the authority of Xanana, who mastered the support of all currents of opinion brought together under that umbrella organization. However, it is possible that the position of FRETILIN may have influenced such reference. Back in 1998 FRETILIN had produced its own draft proposal for a Constitution from its exile headquarters in Mozambique which drew its inspiration both from Portugal and some African experiences. ${ }^{17}$ This draft defined a semi-presidential model, albeit with a rather strong President, and had undergone alterations. As FRETILIN leader Mari Alkatiri put it in an interview with this author:

I had thought the system might be similar to those I knew well in Africa. There is a tendency towards presidentialism in countries like Angola or Mozambique and other former Portuguese colonies, except Cape Verde. 
But when I returned to Timor, or even before, when I visited Xanana in Salemba, I changed my mind.

The seeds for dissension were thus sown.

Xanana decided not to run in the 2001 elections, but he is said to have worked with some aids in a draft project for a constitution. Little is known of this project which did not make it to the Assembly, although "UNTAET political insiders at the time said Gusmão's version of the draft constitution would have formalized his highly centralized authority, while precluding the usual checks and balances expected in a plural political framework" (Kingsbury). It might, however, be in tune with some of the popular ideas about a strong leader expressed in the "popular consultation" process.

No less than five projects for the new constitution were formally presented to the $\mathrm{CA}^{18}$. FRETILIN proposed its own, and so did UDT (a fragmentary project as far as it subsists today in the archive, with various versions), PPT (a very confused project) and KOTA (whose leader, Manuel Tilman, had once been a member of the Portuguese parliament and had in-depth knowledge of that country's constitution). PSD adopted as its own a draft elaborated by Portuguese constitutionalist Jorge Miranda. ${ }^{19}$ In hindsight, it is possible to ascertain that the project presented by the majority party does indeed constitute the basis for what eventually became the Constitution of the Democratic Republic of Timor-Leste (CRDTL), and that the most consistent alternative was PSD's project.

If most observers tend to assume that the dominant role of FRETILIN in the CA explains the fact that the final outcome is similar to that party's proposal, ${ }^{20}$ it is nevertheless necessary to consider that FRETILIN was compelled to negotiate because it failed to dispose of the necessary 60 votes stipulated for the approval of the Constitution. The broad question of government system can be used to illustrate this point.

In general and theoretical terms, the choice of a government system did not generate much debate, since all known projects except the one from UDT explicitly define-if only in nominal terms-their proposal as semi-presidential. Eventual supporters of different models were absent from the Assembly. All drafts conserved in the Library and Archive of National Parliament do bear 
handwritten notes classifying then as "semi-presidentialist," and indeed all share the two definitional features of this kind of government system: the popular election of both the president of the Republic and the Parliament. In detail, however, substantial differences did surface concerning the extension of presidential competences and the balance of power with the government.

Jorge Miranda introduced his contribution by stating that:

this project verges with prudence and substantial normative openness towards a semi-presidential system based on a strong president in relation to the parliament and the government, although not the leader of the executive branch of power and without being assigned duties of daily administration or political management. (Preface to PSD project)

To a significant degree, this project reflects its author's experience with the Portuguese constitution drafting process in 1975-1976, when he was a prominent member of the Constituent Assembly, and his vision of presidential powers pays tribute to the early version that was adopted then, with an eye to the French model. FRETILIN's project, on the other hand, defined the competences and prerogatives of the President of the Republic more narrowly. The final result combines elements of both projects.

If one measures presidential powers using the set of criteria proposed by Siaroff, with some amendments as used in Lobo and Neto for all Lusophone countries (Table 1), FRETILIN's initial proposal would score a mere 4 points, the final result (as observed by Bacelar de Vasconcelos and Sousa da Cunha) is rated with 8.5 points, and Miranda/PSD proposal would have 14 points (my calculations). The full scope of presidential powers is not perfectly reflected in this synthetic model and would increase this contrast. Three examples will illustrate this assertion: the PSD project proposed that the President of the Republic would (a) chair the Council of Ministers on his own right whenever matters pertaining to national defense and foreign relations are on the agenda, (b) possess the right to define "in coordination with the government" the strategic orientations of foreign policy, and (c) have the competence to ask parliament for a revision of the Constitution on specific points. 
Table 1. Presidential powers

\begin{tabular}{llll}
\hline Competence & CRDTL & $\begin{array}{l}\text { FRETILIN } \\
\text { Project }\end{array}$ & $\begin{array}{l}\text { PSD } \\
\text { Project }\end{array}$ \\
\hline Formation of government & 1 & 0 & 1 \\
\hline Dismissal of government & 2 & 0.5 & 2 \\
\hline Dissolution of parliament & 1 & 1 & 3 \\
\hline Censorship & 0 & 0 & 0 \\
\hline Sub- total "non-legislative" competences & 4 & 1.5 & 6 \\
\hline Package veto & 1.5 & 1.5 & 3 \\
\hline Partial veto & 0 & 0 & 0 \\
\hline Decree & 0 & 0 & 0 \\
\hline Exclusive introduction of legislation & 0 & 0 & 1 \\
\hline Budget & 0 & 0 & 0 \\
\hline Referendum & 2 & 1 & 4 \\
\hline Constitutional referenda & 1 & 0 & 0 \\
\hline Sub-total "legislative" competences & 4.5 & 2.5 & 14 \\
\hline Total & 8.5 & 4 & 8 \\
\hline & & & 0 \\
\hline
\end{tabular}

Among the relevant points that pertain to a scrutiny of the Timorese system of government, the following deserve particular attention:

(a) FRETILIN proposed that the President be competent to "appoint as Prime Minister the leader of the party that receives the largest number of votes in legislative elections." The final version of this competence is substantially different and reads that the Prime Minister be appointed according to the proposal made to the president "by the party or alliance of parties with parliamentary majority" (CRDTL, section $85 \mathrm{~d}$ ). The interpretation of this point would constitute the first controversial issue of Ramos-Horta's presidency (July-August 2007), when he decided to appoint as prime minister the leader of 
a post-electoral coalition commanding a majority in parliament rather than the leader of the party which had received the plurality of the popular vote. FRETILIN raucously opposed the move and denounced it as non-constitutional, but failed to raise the matter with the relevant judicial authority.

(b) The final version grants the president competences to "conduct, in consultation with the Government, any negotiation process towards the completion of international agreements in the field of defense and security." (CRDTL, section $87 \mathrm{~d}$ ). This is a milder version of the PSD proposal, and a point not contemplated in FRETILIN's proposal.

(c) FRETILIN proposed that a presidential veto could be overturned by a simple majority in parliament, and a qualified majority of two thirds was considered necessary in a substantial number of cases (CRDTL, section 88).

(d) The critical issue of the president's capacity to dismiss government generated debate and ended up being condensed in the following cases: the president will dismiss the government when two motions of rejection of its program are approved, or when one motion of censure passes in parliament or one motion of confidence is defeated there. Other circumstances include the end of the legislature, and the resignation, death or incapacity of the Prime Minister (Section 112-1). All those are cases in which the president acts only as a consequence of parliamentary decisions or independent facts, and is thus a competence that does not contemplate his own initiative. However, the second part of this section of the Constitution stipulates that the:

President of the Republic shall only dismiss the Prime Minister in accordance with the cases provided for in the previous item and when it is deemed necessary to ensure the regular functioning of the democratic institutions, after consultation with the Council of State. (CDRTL, section 112.2)

This point, in its narrower sense, comes from FRETILIN's original proposal, and had a more generous formulation for the president in the PSD project. 
Here resides one critical issue in the debate about the particular type of semipresidentialism adopted in Timor-Leste. The importance of presidential powers has long been acknowledged by Australian constitutionalist Hilary Charlesworth. The Asia Foundation's statement on the draft constitution also reveals that the adopted formulation contemplates enlarged presidential competences:

As a general matter we would observe that the division of powers between the President and the Government [...] presents potential for conflict. The Article 112 exceptional power of the President to dismiss the Government could provide an opportunity for the President to interfere in the council of ministers if the President and Prime Minister do not get along $[\ldots]$.

There seems to be a number of uncertainties about these [presidential] powers. In many constitutions there is a clear statement that the President exercises his powers on the advice of the Government or the Prime Minister-unless the constitution states otherwise. The absence of any such statement in this Constitution, and the fact that there are clearly some powers which are to involve an independent judgement of the President creates this uncertainty. (9-10)

Recently, Pedro Bacelar de Vasconcelos argued that this provision entitles the President to act upon his own initiative (323).

The picture emerges from these four examples of a political majority in the CA proposing a semi-presidential system that was rather consensual in its broad outline. In the detail of FRETILIN's proposal, however, the role of the prime minister was enhanced and that of the president clearly limited in comparison to competing projects. This project could be classified as premierpresidential-as indeed a significant number of scholars still do for the ultimate result. ${ }^{21}$ But controversy over those terms implied compromise. The shift from the original proposal to the final text reveals a major, if not extraordinary increase in the presidential competences. The initial sharp definition as premier-presidential became considerably blurred and elements commonly found in president-parliamentary sub-types-like the competence to dismiss the 
Prime Minister-emerged in the final text. How do we account for this? What implications can be inferred regarding the quality of Timorese democracy?

Contrary to Elgie's suggestion of an association between the choice of presidential-parliamentary form with a tendency for autocracy, in Timor-Leste the compromises that blurred the clear definition of a premier-presidential system did serve the purpose of allowing greater room both for inclusive governance and for mechanisms of checks and balances. The dominant party did not conceive a solution with a prominent President of the Republic but rather a powerful Prime Minister. The concessions it was forced to make point in the direction of enshrining guarantees for solid democratic principles. They were later to actually facilitate restrictions to some "authoritarian temptations" that observers like Siapno or Simonsen noticed in the performance of the first constitutional government, which raised fears it would establish a form of "dominant party rule" with little room for democratic alternation (Kingsbury and Leach 7). The concessions made by FRETILIN, however, were not sufficient to convince all constituent deputies. In the final vote on the Constitution, 72 voted in favor, 14 against, and one abstained (one was absent). Most parties represented in the CA voted against (including PD, PSD, UDT), revealing how weak the agreements reached actually were among the elite (Garrison 22).

\section{Clio's Mirror}

In order to further our understanding of the broader implications of these institutional choices, it is necessary to consider that many structural features of Timorese political landscape in that period stem from the ways in which some twenty-five years of history continue to affect the present, molding fundamental decisions.

The Portuguese revolution of April 25, 1974, opened up the door for the formation of political parties in Timor, and soon three main options crystallized: the defense of autonomy with ties to Portugal (União Democrática Timorense /Timorese Democratic Union-UDT), integration into Indonesia (Associação Popular Democrátrica Timorense / Timorese Popular Democratic Association-APODETI), and full independence (Frente Revolucionária de Timor-Leste Independente / Revolutionary Front of Independent TimorLeste-FRETILIN). After shifting alliances between the local groups revealed 
shallow bases for agreement, a brief civil war was fought in August 1975 after UDT staged a coup, opposing the supporters of independence to other groups. FRETILIN's victory eventually led to the unilateral proclamation of Independence (November 28, 1975). Indonesia took the initiative of an anschluss (Roff, 1992) officially started on December 7, aided by FRETILIN's opponents, while its supporters fled to the mountains where they kept a guerrilla war alive. The Timorese elite was clearly fractured, and nationalism had not yet permeated the masses.

By virtue of its brutal methods, the Indonesians may have contributed more to the development of a nationalist movement in Timor-Leste than centuries of Portuguese colonialism (Anderson 23-27). Their management of the territory also introduced deep social and cultural changes. In political terms, two converging elements are to be underlined. Indonesian occupation was so brutal that a feeling of rejection soon began to develop; encouraged by organizations such as the Catholic Church, the Timorese refused to accept the new order of things. The visit of Pope John Paul II in 1991 was a testimony to the sentiment of rejection of Indonesian rule. The following year the whole world witnessed the clash between the nationalist aspirations of young Timorese and the brutal repression carried out by Indonesia when Max Stahl circulated his footage of the Santa Cruz massacre. Although one cannot say that the scars opened by the turbulent year of 1975 had been healed, increasingly large parts of the population were turning actively against foreign rule. Urban students' movements like RENETIL gained visibility and weight. This transformation of the nationalist camp included sectors of the elite-like Mario Carrascalão, once the Indonesian-appointed governor of "Tim-Tim Province" - who had sided against FRETILIN and initially supported the invasion. Nationalism was growing stronger and also gaining complexity. The "diplomatic front" animated by political exiles and personalized by José Ramos-Horta became a critical player, and the Nobel Peace Award bestowed upon him and Bishop Belo bears witness to the fact that resistance had become a broad sentiment touching differentiated sectors of the population.

FRETILIN, for its part, had successfully managed to keep the flame of guerrilla warfare alive with widespread support among the people, and 
remained a disciplined organization. However, Xanana Gusmão, who had succeeded Nicolau Lobato as the commander of FALINTIL (the armed forces of the Resistance, but also the armed branch of FRETILIN) when he was shot in late December 1978, underwent a political evolution himself. In mid-1980s he decided to leave FRETILIN and remain as head of FALINTIL, transforming his army into a "nationalist" rather than "revolutionary" organization. Xanana regarded himself increasingly as a nationalist leader capable of entertaining relations with all sectors of society who cared for a different future for Timor. ${ }^{22}$ His move (soon followed by José Ramos Horta) gained him widespread popularity in the country, but also some hard feelings on the part of FRETILIN, whose political leadership was mostly living abroad. Xanana's efforts were channeled to the formation of an umbrella organization, acknowledging as he did that diversity of opinions and trajectories had to find a place in a democratic organization and in a future independent Timor-Leste. The ultimate result of his efforts was the creation of the National Council of the Timorese Resistance (CNRT) in April 1998 and the adoption of its Magna Carta.

In the year 2000, Timor-Leste had a charismatic and popular nationalist leader in the person of Xanana Gusmão, who had not structured his supporters in the form of a political party. He was the leader of a broad umbrella organization, CNRT, where the overwhelming majority of political and civic organizations that had opposed foreign rule had a seat, and tended to promote a consensual approach to decision making. Xanana was in a position to lead the political transition and to assume formal powers, either through a consensual method of recognition of his outstanding role, or by means of formal elections in which he was regarded as virtually unbeatable. His position was tributary of the long established CNRT platform that called for a protracted transitional period during which the umbrella organization should steer the country based on principles of consensual democracy, that is, delaying political competition for a time after having consolidated overarching agreements on fundamental issues. Xanana's platform enjoyed the support of most of the Timorese organizations-though not of FRETILIN.

FRETILIN had developed an approach combining its participation in CNRT with the consolidation of its own position as an independent party, 
carrying the laurels of the long battle fought since 1975. Although by no means the sole bearer of the Resistance banner, FRETILIN was credited with a substantial share of its burden. It was in its best interests to clarify the situation as soon as possible in order to prevent others from having time to organize and extend their own influence. In this light, FRETILIN supported the introduction of competitive forms of democracy to replace the structures of consensual policies in which it felt its weight was not being adequately considered. Mari Alkatiri stated with candor the reasons for rejecting the "constitutional conference" that would have maintained a consensus-type of decision-making:

I opposed the "constitutional conference" because it was an anti-democratic mechanism. I was persuaded that FRETILIN was the strongest force, and so we fought for a compatible status at CNRT's conference. We were not successful. Xanana wanted to treat all organizations on the same footing, with a number of seats equally attributed to all, including the recently formed small parties. We thought that was not fair.

Thus FRETILIN sided with Galbraith's position to introduce competitive democracy at an early stage, and made a strong bet on the CA, presenting most of its leaders as candidates. Those strategic choices were rewarding for this political force, which gained control of a CA vested with ample powers.

The structural and historical features just evoked shed light on FRETILIN's strategy regarding the government system: to concentrate as much power as possible in the hands of government and yield as little as possible to the President. Xanana would certainly be elected as the first president of newly independent Timor-Leste, and since the relationships between FRETILIN and the Resistance leader were strained, it would be a risk to allow him great room for maneuver. The limits on presidential powers, however, could not be so great as to convince Xanana not to run and remain free from any institutional attachment that could render his views poisonous for the whole regime being erected. A compromise was thus necessary.

A combination of specific historical features of the Timorese society that render this country rather atypical in comparison to other decolonizing 
nations with more or less unified nationalist movements (not to mention the rather unusual fact that the political elite of 1974-75 re-emerged in a dominant position in 1999) and a political conjuncture in which short and medium term gains of local actors articulated with the preferences of the international transitional administration, formed the setting in which the choice of government system was made and the specific profile of presidential competences actually drawn. The fact that Xanana accepted to run for President in 2002 is a sign that some form of a deal has been struck that reached beyond the walls of the CA. But it was certainly not the end of history...

Good institutions are unlike Mayakovsky's love boat that "smashed up/ in the dreary routine": they survive political and historical contingencies and deliver according to basic expectations. In Timor-Leste, constitutional provisions have been kept in place, and the ten years of Independence are a case of success marked by important developments that reconfigured the political landscape. To understand how this was possible, one needs to move from a debate on the intrinsic merits of political systems and stress the ways in which they actually respond to relevant features of local society that are politically and historically formatted. As Brennan and Lomasky have suggested, in "liberal democracies, the chief problem may not be so much to identify good institutions as to implement and keep them" (223). The history of Timor-Leste since 2002 has been a constant struggle to combine constitutional principles with contingencies of political competition. It has been a very rich process that requires another opportunity to be fully addressed.

\section{Notes}

1 Research sustaining this essay has been conducted on an informal basis for several years, starting with my first visit to Timor-Leste in 2004 as Visiting Professor at the Universidade Nacional de Timor-Leste (UNTL). It was developed in 2005-2006 when I renewed my association with UNTL and later became UN sponsored advisor to the Presidency of the Republic; in 2007 when I visited Timor-Leste twice, once as a member of the Comunidade dos Países de Língua Portuguesa (CPLP) electoral monitoring team; and again in 2009. The most recent visits (November 2011, March-April and June-August 2012) were included in formal research projects supported by the Fundação para a Ciência e Tecnologia (Research grant FCT SFRH/ BPD/71238/2010; Research Project PTDC/CS-ANT/118150/2010). In Dili I was generously housed by the Fundação Oriente, and I owe special thanks to its former local director, Álvaro 
Antunes. I am indebted to all those political actors who agreed to share their views with me (and who are mentioned in the references section); and to officials at the Library and Archive at the Parlamento Nacional. Special thanks are also due to many friends who helped me remain in contact with the Timorese reality through the years, namely Ana Filipa Carvalho, José Carlos Aragão, José H. Meirelles, Maria Amado, Maria de Jesus Chaves, Marisa Serafim, Nuno Vasco Oliveira, Paulo Vieira and Sónia Neto. I claim full responsibility for any views expressed in this essay that may represent a different opinion or an error of judgment.

2 See Beauvais, Chesterman, and Powell.

3 The justification that they should "broadly reflect the result of the popular consultation" (section 2.3) would rather imply a division of 8 to 2-but that would have meant giving CNRT (Conselho National da Resistência Timorense, or National Council of the Timorese Resistance) the majority of the seats.

4 The United Nations Mission in East Timor (UNAMET) was the preceding mission that had organized the popular consultation, under the aegis of UNDPA.

5 The minutes of the whole process are kept in the Library and Archive of the National Parliament and, unless otherwise stated, constitute the basis for the current section.

6 Note the affirmative, almost authoritarian, tone of this statement, as if no other options were permissible.

7 These papers are kept in the Library and Archive of the National Parliament.

8 Copy of the Magna Carta is available in Mascarenhas \& Silva, Timor Loro'sae.

9 A volume entitled A Report on the National Constitutional Consultation in East Timor, June-July 2001 by the Constitutional Affairs Branch of UNTAET Department of Political Affairs and Timor Sea, under Peter Galbraith, is kept in the Library and Archive of the National Parliament. Unless otherwise stated, it constitutes the basis for this section.

10 See Aucoin and Brandt for a review of its criticism.

11 A file containing the "Pronunciamento do Texto Constitucional nos 13 Distritos e Sub-distritos" is kept in the Library and Archive of the National Parliament. Unless otherwise started, this is the source of information for this section.

12 See Huntington, The Third Wave, and Elgie et al., Semi-presidentialism and Democracy.

13 For an elaboration on the adequacy of this classification, see Feijo, "Semi-presidentialism and the Consolidation of Democracy."

14 For an elaboration on this issue and its relevance to the case of Timor-Leste, see Feijó, "Semi-presidentialism, Moderating Power and Inclusive Governance."

15 The form of causality that better suits the position adopted in this essay is Popper's idea of "propensity" or weighted probability. For more, see his book A World of Propensities.

16 This section is mostly based on interviews with key players in the process, namely, Xanana Gusmão, José Ramos-Horta, Mari Alkatiri and Roque Rodrigues.

17 For more, see Charlesworth and also Aucoin and Brandt.

18 These projects are kept in a file ("Propostas de Constituição de Todos os Partidos Políticos") at the Library and Archive of the National Parliament, and except where explicitly mentioned otherwise, constitute the basis for the present section.

19 Jorge Miranda is a senior professor of constitutional law at the University of Lisbon, and a former politician who took active part in the drafting of the Portuguese Constitution in 1975-76. Later on, he took part in some of its revisions. He also led a group of Portuguese scholars who were involved in the drafting of constitutions in Portuguese speaking African countries, when those countries decided to move away from single-party regimes adopted upon decolonization in 1975 into a multi-party, democratic form of regime. See Gouveia, Constituições. 
20 For example, see Charlesworth, Carter Center, Garrison, and Aucoin and Brandt.

21 See Shoesmith, Reilly, Lobo and Neto, and Elgie, but not Kingsbury.

22 See Mattoso, Niner.

\section{Works Cited}

Alkatiri, Mari. Personal interview. Nov 2011.

Anderson, Benedict. “Imagining East Timor." Arena Magazine 4 (1990): 23-7. Print.

Aucoin, Louis and Michele Brandt. "East Timor Constitutional Passage to Independence". Framing the State in Times of Transition. Case Studies in Constitution Making. Ed. Laurel E. Miller and Louis Aucoin. Washington DC: United States Institute of Peace Press, 2010. 245-274. Print.

Baltazar, Alipio. "An Overview of the Constitutional Drafting Process in East Timor." East Timor Law Journal 9 (2004): http://easttimorlawjournal.wordpress.com/2012/05/19anoverview-of-the-constitution-drafting-process-in-east-timor/

Beauvais, Joel C. “Benevolent Despotism. A Critique of UN State-building in East Timor." New York University Journal of International Law and Politics 33.3 (2001): 1101-1178. Print.

Brennan, G. \& L. Lomasky. Democracy and Decision. The Pure Theory of Electoral Preference. Cambridge: Cambridge UP, 1993. Print.

Carter Center. The East Timor Political and Electoral Observation Project. Atlanta (GA): The Carter Center/The Democracy Program, 2004. Print.

Charlesworth. Hilary. "The Constitution of East Timor, May 20, 2002." International Journal of Constitutional Law 1.2 (2003): 325-344. Print.

Cheibub, José António \& Svitlana Chernykh. "Constitutions and Democratic Performance in SemiPresidential Democracies." Japanese Journal of Political Science 9.3 ( 2007): 269-303. Print.

"Are Semi-Presidential Constitutions Bad for Democratic Performance?" Constitutional Political Economy 20.3/4 (2009): 202-229. Print.

Chesterman, Simon. "State Building and International Law." University of Westminster. 19 Dec 2010. Web. 5 Feb 2012.

Chopra, Jarat. “The UN Kingdom of East Timor." Survival 42. 3 (2000): 27-39. Print.

Democratic Republic of Timor-Leste. Constitution of the Democratic Republic of Timor-Leste. Dili: Parlamento Nacional, 2002. Print.

Duverger, Maurice. Échec au Roi. Paris: Albin Michel, 1978. Print.

. "A New Political System Model: Semi-Presidential Government". European Journal of Political Research 8.2 (1980): 167-187. Print.

"Régime Semi-présidentiel." Dictionnaire Constitutionnel. Ed. Oliver Duhamel and Yves Mény. Paris: PUF, 1992. 901-904. Print.

—. Le Système Politique Français. Droit Constitutionel et Science politique. Paris: PUF («édition entièrement refondue »), 1996. Print.

East Timor Transitional Authority, Standing Committee on Political Affairs. Report on the Political Transition Calendar. Library and Archive of the National Parliament of TimorLeste. 22 February 2001. Print. 
Elgie, Robert. Semi-Presidentialism: Sub-types and Democratic Performance. Oxford: Oxford UP. 2011. Print.

Elgie, Robert and Sophie Moestrup. Semi-Presidentialism Outside Europe. London: Routledge, 2007. Print.

Elgie, Robert, Sophie Moestrup, and Yu-Shan Wu. Semi-Presidentialism and Democracy. London: Palgrave-Macmillan, 2010. Print.

Feijó, Rui Graça. "Semipresidentialism and the Consolidation of Democracy." The Politics of Timor-Leste. Ed. Michael Leach and Damien Kingsbury. Ithaca: Cornell Southeast Asia Program. 2012.pp. 45-68. Print.

_ "Semi-presidentialism, Moderating Power and Inclusive Governance. The Experience of Timor-Leste in Consolidating Democracy." Democratization 20.1 (2012): http://dx.doi. org/10.1080/13510347.2012.732068

Freedom House. Freedom House, n.d. Web. 12 Feb 2013.

Garrison, Randall. The Role of Constitution-Building Processes in Democratization. Stokholm: International IDEA, 2005. Print.

Gouveia, Jorge Bacelar. As Constituições dos Estados de Língua Portuguesa. 2nd ed. Coimbra: Almedina, 2005. Print.

Gusmão, Xanana. Personal interview. Nov 2009.

Horta, José Ramos [or Ramos-Horta, as appears elsewhere?]. Nobel Prize acceptance speech. Nobelprize.org. 10 Dec 1996. Web. 5 Feb 2013.

_. Personal interview. Nov 2009.

—. Personal interview. Nov 2011.

Huntington, Samuel P. The Third Wave: Democratization in the Late Twentieth Century. Norman: U of Oklahoma P, 1991. Print.

Kingsbury, Damien. ”Timor-Leste's Political System: Semi-Presidentialism or Parliamentary Republic?" Timor-Leste: História, Politica e Deesnho Institucional. Ed. Rui Graça Feijó. Coimbra: CES/Almedina, Forthcoming:. Print.

Kingsbury, Damien and Michael Leach. East Timor: Beyond Independence. Melbourne: Monash UP, 2007. Print.

Leach, Michael, and Damien Kingsbury. The Politics of Timor-Leste. Ithaca (NY): Cornell Southeast Asia Program, 2012. Print.

Lobo, Martina Costa, and Octavio Amorim Neto. O Semipresidencialismo nos países de língua portuguesa. Lisboa: Imprensa de Ciências Sociais, 2009. Print.

Lutz, Nancy M. "Constitutionalism as Public Culture in East Timor." Law and Society Association Meeting. Pittsburgh, PA. 7 June 2003. Lecture.

Mascarenhas, João Mário and João Elviro Matilde da Silva, eds. Timor Loro Sảe. O nascimento de uma Nação. Lisboa: Biblioteca Museu República e Resistência, 2000. Print.

Mattoso, José. A Dignidade. Konis Santana e a Resistência Timorense. Lisboa: Temas e Debates, 2005. Print.

Miranda, Jorge, ed. Timor e o Direito. Lisboa: Associação Académica da Faculdade de Direito da Universidade de Lisboa, 2001. Print.

Moestrup, Sophia. "Semi-presidentialism in Young Democracies. Help or Hindrance?" in Elgie et al (eds) Semi-presidentialism outside Europe, pp. 30-55 
Niner, Sara. Xanana. Leader of the Struggle for Independent Timor-Leste. Melbourne: Australia Scholarly Publishing, 2009. Print.

Pasquino, Gianfranco. "The Advantages and Disadvantages of Semi-presidentialism: a Western European Perspective." Semi-presidentialism Outside Europe. Ed. Robert Elgie and Sophia Moestrup. London: Routledge, 2007: 14-29. Print.

Polity IV Project. Center for Systemic Peace. Center for Systemic Peace, 15 Feb 2012. Web. 12 Feb 2013.

Popper, Karl. A World of Propensities. Bristol: Toemmes Press, 1990. Print.

Powell, Samantha. Chasing the Flame. Sergio Vieira de Mello and the Fight to Save the World. London: Allen Lane, 2008. Print.

Reilly, Benjamin. "Semi-Presidentialism and Democratic Development in East Asia." SemiPresidentialism and Democracy. Ed Robert Elgie, et al. Basingstroke and New York: Palgrave Macmillan, 2011. 117-133. Print.

Rodrigues, Roque. Interviews with the author (November 2011, April 2012)

Roff, Sue Rabbitt. Timor's Anschluss: Indonesian and Australian Policy in East Timor, 1974-76. Lampeter, Dyfed: Edwin Mellen Press, 1992. Print.

Samuels, David, and Matthew Shugart. Presidents, Parties, Prime Ministers: A Framewok for Analysis. Cambridge: Cambridge UP, 2010. Print.

Sartori, Giovanni. Comparative Constitutional Engineering. Basingstoke and London: Palgrave Macmillan, 1994. Print.

Shoesmith, Dennis. "Timor-Leste: Semi-presidentialism and the Democratic Transition in a New, Small State." Semi-presidentialism Outside Europe. Ed. Robert Elgie et al. London and New York: Routledge, 2007. 219-236. Print.

_. "Remaking the State in Timor-Leste: The Case for Constitutional Reform". 17 ${ }^{\text {th }}$ Biennial Conference of the Asian Studies Association of Australia. Melbourne. 1-3 July 2008. Lecture.

Shugart, Matthew Soberg, and John M. Carey. Presidents and Assemblies: Constitutional Design and Electoral Dynamics. Cambridge: Cambridge UP, 1992. Print

Siapno, Jacqueline. “Timor-Leste-on the path to authoritarianism?" Southeast Asian Affairs 1 (2004): 325-342. Print.

Siaroff, Alan. "Comparative Presidencies: The Inadequacy of the Presidential, Semipresidential and Parliamentary Distinction.” European Journal of Political Research 4.3 (2003): 287 312. Print.

Simonsen. Sven Gunnar. "The Authoritarian Temptation in East Timor-Nation Building and the Need for Inclusive Governance." Asian Survey 46.4 (2004): 575-596. Print.

Smythe, Patrick A. 'The Heaviest Blow'. The Catholic Church and the East Timor Issue. Munster: Lit Verlag, 2004. Print.

Sousa, Lurdes Silva-Carneiro. Some Facts and Comments on East Timor 2001 Constituent Assembly Election. Lisboa: CEPESA, 2001. Print.

Tansey, Oisin. Regime-Building: Democratization and International Administration. Oxford.: Oxford UP. 2009. Print.

United Nations Transitional Administration of East Timor, Department of Political Affairs and Timor Sea. A Report on the National Constitutional Consultation in East Timor, June- 
July 2001. Library and Archive of the National Parliament of Timor-Leste, September 2001. Print.

United Nations Transitional Administration of East Timor, Electoral Affairs. Working Papers \#1 through \#8. Library and Archive of the National Parliament of Timor-Leste. Print.

Various Authors. File Comentários e Sugestões sobre a Constituição (I). Library and Archive of the National Parliament of Timor-Leste. Print.

—. File Pronunciamento do Texto Constitucional nas 13 Distritos e Sub-distritos. Library and Archive of the National Parliament of Timor-Leste. Print.

—. File Propostas de Constituição de todos os Partidos Politicos. Library and Archive of the National Parliament of Timor-Leste. Print.

Vasconcelos, Pedro Bacelar de. "Timor Leste: a caminho da Independência." O Mundo em Português vol 2 number 19. Web. (accessed at www.ieei.pt/publicacoes/artigo. php?artigo $=853$ on 14 May 2012)

—_. "A Transição em Timor-Leste (1999-2002)." Timor-Leste: da Nação ao Estado. Ed. Rui Centeno and Rui Novais. Porto: Afrontamento, 2006. 57-71. Print.

—. Constituição Anotada da República Democrática de Timor-Leste. Braga: Direitos Humanos-Centro de Investigação Interdisciplinar, Escola de Direito da Universidade do Minho, 2011. Print.

Vasconcelos, Pedro Bacelar de, and Ricardo Sousa da Cunha. "Semipresidencialismo em Timor: um equilíbrio institucional dinâmico num contexto crítico." O Semipresidencialismo nos Países de Língua Portuguesa. Eds. Marina Costo Lobo and Octávio Amorim Neto. Lisboa: Imprensa de Ciências Sociais, 2009. 231-260. Print.

Rui Graça Feijó (D.Phil, Oxon) is Assistant Researcher at the Centro de Estudos Sociais, University of Coimbra. He is the author of Paisagem Tropical com Gente Dentro. Ensaios de análise política sobre a construção da democracia timorense (2006), as well as several articles and book chapters on the construction of Timorese identity and its democratic process after 1999. His current research focuses on the dynamics of power at grassroots level, encompassing both sucos and aldeias and the novel municipal institutions. 